and to help us better appreciate the achievements of liberal democracy (pp. 172, 174).

Johnson's scholarship is impressive and she presents Habermas's ideas in a clear and accessible manner. This book is therefore valuable for postgraduates and researchers working in this area because it provides an exposition of the main developments in Habermas's work and an extensive outline of the arguments of his main critics. However, it is surely difficult to write a book on Habermas that adds a new and creative dimension to the extensive literature. What is interesting about Johnson's book is that she is both sympathetic and critical in her engagements with Habermas's 'radical reformist' ambitions for the public sphere and his aims in providing an emancipatory critical theory of society.

Indeed, Johnson fulfils her own aim of examining the notion of the public sphere in Habermas's development and by showing that he theorizes a more inclusive and participatory conception of public autonomy and private right than the one offered by various forms of liberalism. She makes it clear how important the notion of the public sphere is in the 21st century and how Habermas offers us an appreciation of 'what the stakes are' (p. 175). However, her book would have benefited from reconnecting Habermas's recent work with the theorists mentioned in the first chapter such as Bauman and Touraine and by providing practical or institutional suggestions about how the public sphere can be 'rescued'. Moreover, an examination of the changing nature of contemporary social movements such as the 'alternative globalization movement' and how these either fit into or challenge Habermas's framework would have strengthened her argument by focusing attention on the contemporary relevance of the public sphere as means of resisting neo-liberalism on a global setting.

Gulshan Khan

University of Nottingham, UK

\title{
Multiculturalism without Culture
}

Anne Phillips

Princeton University Press, Princeton, NJ, 2007, $202 p p$.

ISBN: 100691129444.

Contemporary Political Theory (2008) 7, 446-449. doi:10.1057/cpt.2008.8

Anne Phillips readily admits that the title of her new book is 'somewhat polemical' (p. 9). It is also to some degree misleading. She is not in favour of a politics of multiculturalism that does away with any conception of culture. 
Rather, her argument is that a multicultural politics, which abandons a particular conception of culture, can remain robust enough both to address inequalities between 'cultural groups', and to be compatible with the pursuit of 'gender equality and women's rights' (pp. 8-9).

Phillips's key move, then, is to reject a conception of culture found both in popular discourse and in some strands of contemporary political theory and feminist thought. According to this account, cultures have clear boundaries, are internally homogeneous, have static identities, and are strongly differentiated from each other. Furthermore, cultures have the full agreement of their members, command their exclusive loyalty, and fully explain their behaviour. The problems presented by this conception of culture are many and various. Three are of particular importance. First, it exaggerates the degree and depth of cultural disagreement, making rapprochement between cultures extremely difficult. Second, it leads to an exoticization of culture, suggesting that non-Western peoples and minorities have cultural traditions, while 'we' have moral values (p. 31). Third, it suggests that the behaviour of those exotic others is fully determined by their cultural identities, whereas we choose to comply with - or sometimes to go against - our values. On this account, it seems, there is a stark choice to be made between culture and autonomy.

Phillips's alternative conception of culture draws on the work of contemporary anthropology. On this account, cultures are unbounded since they draw elements from many sources, they are strongly heterogeneous and include distinct sub-cultures, they are without fixed identity and so can change over time, and they are not radically distinct from their rivals. Furthermore, cultures are marked by power struggles about the meaning of their various elements, they are only one source of identification for their members, and, while they may influence or partly constrain members' actions, they by no means fully determine them. According to Phillips, this alternative conception of culture enables us to circumvent the various dangers that she associates with its rival. First, we can avoid exaggerating the problem of cultural difference. Human actions that may initially appear odd can generally be explained by seeing how a relatively universal set of human motivations lead people to choose particular courses of action in specific contexts. Second, it helps us to see that all humans, and not just exotic others, are influenced by culture, which, as Phillips says, mediates our relationship to the social world (p. 52). Third, it can enable us to develop a more nuanced account of the role of culture in the explanation of human action. For Phillips, there is no exclusive choice between culture and autonomy: although all humans are influenced by a variety of cultures, it does not follow that they are merely the captives of those cultures (p. 176). While culture is relevant to the explanation of human action, it is never simply a determinant of such action (p. 131). Indeed, it is always 
necessary, in explaining individuals' conduct, to show how specific cultural influences bear on their particular life histories (pp. 129-130).

Phillips believes that the employment of this conception of culture will make possible a 'modest' multiculturalism that avoids assuming that the majority's norms and practices treat all individuals equally, which is sensitive to cultural diversity, and which accepts moreover that cultural differences sometimes need to be taken into account (pp. 126-127). At the same time, such a multiculturalism will establish strict limits to tolerable behaviour, even when it is claimed that such behaviour is mandated by membership of a particular culture. Harm to minors, and physical and mental violence to adults are strictly ruled out. A commitment to equal treatment of all individuals (pp. 34-36) and an acceptance of the democratic legitimacy of law (p. 165) place further limits on acceptable behaviour. Phillips also offers a subtle analysis of the conditions that are necessary if the right of exit from a cultural group is to be exercised without excessive cost to individuals (pp. 140-150), and, towards the end of the book, she draws on her work on the politics of presence in order to suggest measures that will enable individuals who choose to stay attached to a cultural group to initiate internal debate on its character and so reshape it from within.

Multiculturalism without Culture is a thoughtful and stimulating book, which should be read by anyone interested in the politics of multiculturalism. It is impossible to disagree with its central thesis that political theorists, feminist thinkers, policy makers, and legal practitioners need a more subtle and nonessentialist account of culture if they are to deploy it appropriately in both theory and practice. In fact, it is the final group - legal practitioners - who come out of Phillips's book best. Her analysis of legal decisions concerning issues of multiculturalism suggests that it is the legal system that is able to consider the role of culture in individuals' lives in an appropriately nuanced way.

Of course, no book is perfect, so in the space that remains, I make three critical remarks. First, given that one of Phillips' central aims is to show that culture and autonomy are not exclusive alternatives, it is odd that she does not tackle Will Kymlicka's work at greater length. While she considers in detail the argument that culture curtails choice (pp. 106-126), she simply sets aside his alternative account, according to which culture is a necessary condition for autonomy (pp. 105-106). Second, Phillips retreats from what some would see as the logical implication of her non-essentialist account of culture - namely, a politics of equality which makes no reference to culture whatsoever. She does so on two grounds: the first is that the deconstruction of the idea of race - and culture today often serves as a placeholder for race - does not make racists go away (pp. 53-56). This must be right, but it does not follow that anti-racism should itself invoke an idea of race or culture. Phillips's other reason for not going all the way down the deconstructive route is that, while anthropologists may have shown that culture is a fiction, it still plays a real role in people's lives 
(pp. 51-52). This, however, is an uncomfortable place to be in. If Phillips accepts the anti-essentialist account of culture, but wants to respect the fact that some people believe 'their' culture to have certain essential properties, then she appears to be reproducing the distinction she takes pains to criticize namely, the idea that 'we' have values, while 'they' have culture. Third (and this is not so much a criticism as a request for more of the same), I would have liked to see further development of the democratic side of Phillips' position. She summarizes her well-known argument for a 'politics of presence' that would increase the political representation of members of cultural groups (pp. 167-168), and she also makes various suggestions about how to enable democratic debate to take place within such groups (pp. 169, 177). But these suggestions are rather patchy and underdeveloped. More on this side of Phillips's argument would help to show how a politics of presence and multiculturalism without culture could usefully come together in the interests of both individual autonomy and cultural equality.

Simon Thompson University of the West of England, UK

\author{
John Rawls \\ Catherine Audard \\ Acumen, London, 2006, 336pp. \\ ISBN: 1844650510
}

Contemporary Political Theory (2008) 7, 449-451. doi:10.1057/cpt.2008.9

The strength of Catherine Audard's discussion of Rawls lies in its integration of Rawls's earlier A Theory of Justice (1971) and his later works, primarily Political Liberalism (1993) and The Law of Peoples (1999). Although the book appears in Acumen's 'Philosophy Now' series, which is intended to provide introductions to major contemporary philosophers, a reader coming to Rawls for the first time would struggle to grasp Audard's argument. Nonetheless, she does provide a useful holistic interpretation of Rawls. As the translator into French of $A$ Theory of Justice her work is informed by a sure - if controversial - grasp of Rawls, as well as a refreshingly non-Anglo-Saxon perspective.

Audard emphasizes the practical nature of Rawls's enterprise: 'the reader is at the centre of Rawls' preoccupations, especially the reader as representative of fellow citizens' (p. 10, her emphasis). She sees in Rawls a priority of democracy over philosophy, albeit a democratic culture informed by philosophical thought. There is implicit in a democratic culture a conception of justice and it is the task of 'theory' to clarify that conception, along with 